\title{
PENGARUH DIVIDEN PAYOUT RATIO, EARNING PER SHARE DAN KURS DOLLAR TERHADAP HARGA SAHAM
}

\author{
Hernawati Pramesti \\ Mujiyono \\ Program Studi Akuntansi, Fakultas Ekonomi, Universitas Kristen Surakarta \\ Email korespondensi: hernawati73@yahoo.co.id
}

\begin{abstract}
ABSTRAK
Penelitian ini bertujuan untuk menganalisis pengaruh faktor dividend payout ratio, earning per share dan kurs dollar terhadap harga saham perusahaan manufaktur yang terdaftar di BEI tahun 2016 sampai 2018. Populasi semua perusahaan yang terdaftar di Bursa Efek Indonesia tahun 2016 sampai 2018. Sampel perusahaan manufaktur yang terdaftar di Bursa Efek Indonesia dari tahun 2016 sampai 2018. Dengan kriteria pengambilan sampel dengan purposive sampling. Metode yang digunakan untuk menguji hipotesis yang diajukan uji t dan uji f. Berdasarkan hasil analisis data dapat dinyatakan simpulan sebagai berikut: $\mathrm{H}_{\mathrm{a} 1}$ ditolak, hal ini berarti DPR tidak berpengaruh signifikan terhadap harga saham. $\mathrm{H}_{\mathrm{a} 2}$ diterima, hal ini berarti variabel EPS mempunyai pengaruh yang signifikan terhadap harga saham. $\mathrm{H}_{\mathrm{a}}$ diterima, hal ini berarti variabel kurs dollar mempunyai pengaruh yang signifikan terhadap harga saham. Hasil analisis uji F disimpulkan terdapat pengaruh yang signifikan dari DPR, EPS dan kurs dollar secara bersama-sama terhadap harga saham yang terdaftar di BEI.
\end{abstract}

Kata Kunci: dividend payout ratio (DPR), earning per share (EPS), kurs dollar, harga saham

\begin{abstract}
This study aims to analyze the effect of the dividend payout ratio, earnings per share and dollar exchange rate on the stock prices of manufacturing companies listed on the IDX from 2016 to 2018. The population of all companies listed on the Indonesia Stock Exchange from 2016 to 2018. Sample listed manufacturing companies on the Indonesia Stock Exchange from 2016 to 2018. With the sampling criteria with purposive sampling. The method used to test the hypothesis proposed by the $t$ test and $\mathrm{f}$ test. Based on the results of data analysis, the following conclusions can be stated: $\mathrm{H}_{\mathrm{a} 1}$ is rejected, this means that the DPR does not have a significant effect on stock prices. $\mathrm{H}_{\mathrm{a} 2}$ is accepted, this means that the EPS variable has a significant effect on stock prices. $\mathrm{H}_{\mathrm{a} 3}$ is accepted, this means that the dollar exchange rate variable has a significant effect on stock prices. The results of the F test analysis concluded that there is a significant effect of the DPR, EPS and the dollar exchange rate simultaneously on stock prices listed on the IDX.
\end{abstract}

Keywords: dividend payout ratio (DPR), earning per share (EPS), dollar exchange rate, stock prices 


\section{PENDAHULUAN}

Kegiatan pengembangan perusahaan tentunya membutuhkan dana yang cukup besar. Untuk memenuhi kebutuhan dana tersebut tentunya diperlukan usaha untuk mencari tambahan dana (berupa fresh money) yang digunakan perusahaan sebagai pengganti ataupun sebagai penambah dana yang sedang dijalankan ataupun untuk pengembangan dan perluasan bidang usaha. Dalam rangka pemenuhan dana tersebut selain mencari pinjaman, merger, perusahaan dapat mencari tambahan modal dengan cara mencari pihak lain yang berpartisipasi dalam menanamkan modalnya. Hal ini dapat dilakukan dengan penjualan sebagian saham dalam bentuk efek kepada masyarakat luas. Usaha ini dikenal dengan istilah penawaran umum (go public) di pasar modal.

Investor yang menanamkan dananya sangat berkepentingan terhadap laba saat ini dan laba di masa yang akan datang serta adanya stabilitas laba. Sebelum menanamkan dananya, investor harus mempunyai informasi tentang kemampuan perusahaan untuk menghasilkan laba. Salah satu kriteria yang sering digunakan investor menentukan pilihan investasinya adalah kemampuan perusahaan dalam membayar dividen. Besar-kecilnya pembayaran dividen yang akan diberikan perusahaan dipengaruhi oleh kebijakan pembayaran dividen yang ditentukan oleh perusahaan.

Selain variabel dividen payout ratio, terdapat juga hasil penelitian tentang variabel earning per share terhadap harga saham. Azis (2005) dalam penelitiannya menemukan bahwa pengaruh Earning Per Share (EPS) dan pertumbuhan penjualan terhadap perubahan harga saham pada perusahaan makanan dan minuman yang terdaftar di Bursa Efek Jakarta. Penelitian ini mengemukakan bahwa secara parsial EPS berpengaruh signifikan terhadap perubahan harga saham dan pertumbuhan penjualan tidak berpengaruh terhadap harga saham perusahaan makanan dan minuman. Namun secara simultan, EPS dan pertumbuhan penjualan berpengaruh terhadap harga saham. Hasil penelitian itu sedikit berbeda dengan penelitian yang dilakukan Pranowo (2009) yang meneliti pengaruh beberapa kinerja keuangan terhadap harga saham perusahaan. Penelitian itu menunjukkan bahwa secara simultan variabel earning per share berpengaruh negatif sangat meyakinkan terhadap perubahan harga saham. Artinya, perubahan yang terjadi terhadap variabel earning per share, berbanding terbalik dengan perubahan harga. Namun, secara parsial, hasil penelitian menunjukkan EPS berpengaruh positif meyakinkan terhadap harga saham. Artinya, perubahan pada EPS akan diikuti searah dengan perubahan harga saham. Berdasarkan hal tersebut di atas, maka permasalahan dalam penelitian ini adalah apakah dividen payout ratio, earning per share dan kurs dollar secara simultan berpengaruh terhadap perubahan harga saham perusahaan manufaktur yang terdaftar di BEI? Dan apakah dividen payout ratio, earning per share dan kurs dollar secara parsial berpengaruh terhadap perubahan harga saham perusahaan manufaktur yang terdaftar di BEI?

\section{KAJIAN LITERATUR}

\section{Pengertian Dividen Payout Ratio (DPR)}

Menurut Martono dan Harjito (2005), dividen merupakan keputusan pembagian laba yang diperoleh perusahaan pada akhir tahun kepada pemegang saham, apakah dalam bentuk dividen atau akan ditahan untuk menambah modal guna pembiayaan investasi di masa yang akan datang. Warsono (2003) menjelaskan bahwa dividen adalah bagian dari laba yang tersedia bagi pemegang saham biasa yang dibagikan kepada para pemegang saham. Hanafi (2004) menyatakan bahwa dividen merupakan kompensasi yang diterima oleh pemegang saham, di samping capital gain. Dividen ini untuk dibagikan kepada para pemegang saham sebagai dari keuntungan dari laba perusahaan. Berdasarkan pendapatpendapat tersebut maka dapat disimpulkan bahwa dividen adalah pembagian laba yang dihasilkan oleh perusahaan, baik berasal dari laba periode saat ini ataupun laba periode sebelumnya kepada pemegang saham sebagai hasil atas investasi.

Debt to Equity Ratio menunjukan persentase penyediaan dana oleh pemegang saham terhadap pemberi pinjaman. Semakin tinggi rasio, semakin rendah pendanaan perusahaan yang disediakan oleh pemegang saham (Kasmir, 2008). Persentase dari pendapatan yang akan dibayarkan kepada para pemegang saham sebagai cash dividend disebut dividen payout ratio. Besarnya DPR suatu 
perusahaan dapat diketahui dari informasi laporan keuangan suatu perusahaan (Riyanto, 1998).

$$
\text { Dividen Payout Ratio }=\frac{\text { Dividen per Share }}{\text { Earning per Share }}
$$

\section{Pengertian Earning Per Share (EPS)}

Earning Per Share (EPS) adalah bentuk pemberian laba yang diberikan kepada para pemegang saham dari setiap lembar saham yang dimiliki (Fahmi, 2012). EPS adalah rasio yang menggambarkan berapa besar laba diperoleh pemegang saham setiap lembar saham. Semakin besar rasio ini semakin berdampak baik bagi pemegang saham karena semakin besar laba yang akan diperoleh. Rasio ini menggambarkan seberapa besar kemajuan yang telah dicapai perusahaan dalam menghasilkan laba yang lebih banyak yang nantinya akan dibagikan kepada investor. Harga saham perusahaan akan mengalami kenaikan yang disebabkan oleh permintaan yang meningkat apabila rasio EPS meningkat. Hal ini didukung dengan penelitian yang dilakukan oleh Amanda (2013) dan Sanjaya (2017) yang menyatakan bahwa EPS berpengaruh signifikan terhadap Harga Saham. Makin tinggi nilai EPS akan menggembirakan pemegang saham karena semakin besar laba yang disediakan untuk pemegang saham (Darmadji dan Hendy, 2001).

\section{Pengertian Kurs Dollar}

Kurs sebagai salah satu indikator yang mempengaruhi aktivitas di pasar saham maupun pasar uang karena investor cenderung berhati-hati melakukan investasi. Menurunnya kurs Rupiah terhadap mata uang asing khususnya Dolar AS memiliki pengaruh negatif terhadap ekonomi dan pasar modal (Sitinjak dan Kurniasari, 2003). Kurs valuta adalah harga satu unit valuta yang ditunjukkan dalam valuta lain (Sukirno, 2010).

Menurut Hady (2013), mata uang asing (valas) ditetapkan sebagai alat valuta asing dan alat pembayaran lain yang digunakan untuk membiayai transaksi keuangan internasional yang berisi surat-surat nilai tukar resmi di bank sentral. Mata uang yang sering digunakan sebagai metode pembayaran dan rekening dalam keuangan internasional disebut mata uang keras, dan itu merupakan mata uang yang nilainya relatif stabil dan harus dibayar atau dihargai sesuai dengan mata uang lain.

\section{Pengertian Harga Saham}

Harga saham adalah nilai surat saham yang mencerminkan kekayaan perusahaan yang mengeluarkan saham tersebut, dimana perubahan dan fluktuasinya sangat ditentukan oleh kekuatan permintaan dan penawaran yang terjadi di pasar bursa (Linzzy, 2015). Harga saham memiliki nilai penting bagi perusahaan, jika harga saham suatu perusahaan tinggi maka akan memberikan kesempatan bagi perusahaan untuk mendapatkan tambahan investasi dari dari kenaikan harga sahamnya. Untuk investor, jika harga saham suatu perusahaan terus meningkat, maka investor akan menyimpulkan bahwa perusahaan tersebut memiliki kinerja yang baik (Samsul, 2006).

\section{HIPOTESIS}

Ha1: Dividen payout ratio mempunyai pengaruh positif terhadap perubahan harga saham perusahaan manufaktur yang terdaftar di BEI.

Ha2: Earning per share mempunyai pengaruh positif terhadap perubahan harga saham perusahaan manufaktur yang terdaftar di BEI. Ha3: Kurs dollar mempunyai pengaruh negatif terhadap perubahan harga saham perusahaan manufaktur yang terdaftar di BEI.

\section{METODE}

\section{Populasi dan Sampel}

Populasi dalam penelitian ini adalah semua perusahaan go public yang terdaftar di Bursa Efek Indonesia tahun 2016 sampai 2018, dan sampelnya adalah semua perusahaan manufaktur yang terdaftar di Bursa Efek Indonesia dari tahun 2016 sampai 2018. Teknik pemilihan sampel dengan purposive sampling. Kriteria sampel penelitian:

a. Saham yang dipilih adalah saham perusahaan manufaktur yang menerbitkan laporan keuangan dari tahun 2016 sampai 2018 secara berturut-turut.

b. Saham yang dipilih adalah saham perusahaan manufaktur yang memperoleh laba pada tahun 2016 sampai 2018 berturutturut.

c. Saham yang dipilih adalah saham perusahaan manufaktur yang membayar 
dividen pada tahun 2016 sampai 2018 secara berturut-turut.

\section{Pengukuran Variabel}

Dividen payout ratio. Dividen payout ratio merupakan persentase dari pendapatan yang akan dibayarkan kepada pemegang saham. Semakin tinggi dividen payout ratio perusahaan maka semakin kecil dana yang tersedia untuk ditanamkan kembali ke perusahaan. Variabel ini diukur dengan menggunakan rumus sebagai berikut (Riyanto, 1998:266):

Dividen payout ratio $=\frac{\text { Dividen per Share }}{\text { Earning per Share }}$

Earning Per Share (EPS). Earning per share Merupakan perbandingan laba bersih per lembar saham dengan jumlah saham. Informasi EPS perusahaan menunjukkan besarnya laba bersih yang siap dibagikan bagi semua pemegang saham perusahaan. Variabel ini diukur dengan menggunakan rumus (Simamora, 2000:530):

EPS $=\frac{\text { Laba bersih }- \text { dividen saham preferen }}{\text { Laba bersih dividen saham preferen }}$

Kurs dollar. Nilai tukar Rupiah/US\$ menunjukkan nilai dari mata uang dolar AS yang ditranslasikan dengan mata uang Rupiah. Sebagai contoh, US\$ 1 = Rp 14.252,- Data yang diambil adalah Nilai tukar Rupiah/US\$ pada bulan Desember 2016 sampai bulan Desember 2018.

\section{Harga Saham}

Harga saham yang diambil pada penutupan akhir tahun (closing price).

\section{Teknik Analisis Data}

\section{Analisis Regresi Linear Berganda}

Secara umum rumus dari regresi linear berganda dari tiga variabel $\mathrm{X}$ (tiga prediktor) untuk sampel dapat ditulis sebagai berikut (Sumadiningrat, $2007: 155$ ):

$$
\mathrm{Y}=\beta_{0}+\beta_{1} \mathrm{X}_{1}+\beta_{2} \mathrm{X}_{2}+\beta_{3} \mathrm{X}_{3}+
$$

Model penelitian regresi dalam penelitian ini dinyatakan sebagai berikut:
Harga saham $=\mathrm{a}+\beta_{1}(\mathrm{DPR})+\beta_{2}(\mathrm{EPS})+\beta_{3}$ (kurs dollar) $+\mathrm{e}$

Dimana :

$$
\begin{array}{ll}
\text { a } & : \text { konstanta } \\
\beta_{1}, \beta_{2}, \beta_{3} & : \text { koefisien regresi } \\
\text { DPR } & : \text { dividen payout ratio } \\
\text { EPS } & : \text { earning per share } \\
\text { Kurs } & : \text { kurs dollar }
\end{array}
$$

\section{Uji Hipotesis}

\section{Uji F}

Pengujian ini dimaksudkan untuk mengetahui apakah variabel independen secara bersama - sama berpengaruh terhadap variabel dependen. Kriteria pengujian :

a) $H_{o}$ diterima dan $H_{a}$ ditolak, apabila $F_{\text {hitung }}<F_{\text {tabel }}$ Ini menunjukkan bahwa variabel independen secara bersama - sama tidak berpengaruh terhadap variabel dependen.

b) $H_{o}$ ditolak dan $H_{a}$ diterima, apabila $F_{\text {hitung }}>F_{\text {tabel }}$ Ini menunjukkan bahwa variabel independen secara bersama sama berpengaruh terhadap variabel dependen (Ghozali, 2002).

\section{Uji t}

Pengujian ini dimaksudkan untuk mengetahui pengaruh masing-masing variabel independen secara parsial terhadap variabel dependen. Kriteria pengujian :

a) $H_{o}$ diterima dan $H_{a}$ ditolak, apabila $t_{\text {hitung }}<t_{\text {tabel }}$ Ini menunjukkan bahwa variabel independen secara parsial tidak berpengaruh terhadap variabel dependen.

b) $H_{o}$ ditolak dan $H_{a}$ diterima, apabila $t_{\text {hitung }}>t_{\text {tabel }}$ Ini menunjukkan bahwa variabel independen secara parsial berpengaruh terhadap variasi dependen (Ghozali, 2002).

\section{HASIL DAN PEMBAHASAN}

\section{Deskripsi Data}

Jumlah seluruh perusahaan manufaktur yang terdaftar di BEI selama periode 2016 sampai dengan 2018 adalah 149 perusahaan manufaktur, sedangkan yang memenuhi kriteria untuk menjadi sampel terdapat 14 perusahaan.

Tabel 1. Hasil Pengambilan Sampel 


\begin{tabular}{llc}
\hline No & \multicolumn{1}{c}{ Keterangan } & Jumlah \\
\hline 1. & $\begin{array}{l}\text { Jumlah perusahaan yang mengeluarkan laporan } \\
\text { keuangan pada tahun 2016 sampai 2018 secara berturut- } \\
\text { turut. }\end{array}$ & 394 \\
2. & $\begin{array}{l}\text { Jumlah perusahaan yang bukan merupakan perusahaan } \\
\text { manufaktur. }\end{array}$ & $(245)$ \\
3. Jumlah perusahaan yang tidak memperoleh laba pada & (46) \\
tahun 2016 sampai 2018. & $\begin{array}{l}\text { Jumlah perusahaan yang tidak membayar dividen pada } \\
\text { tahun 2016 sampai 2018. }\end{array}$ \\
\hline Jumlah sampel yang diteliti & (89) \\
\hline
\end{tabular}

\section{Analisis Regresi Berganda}

Berdasarkan pada hasil uji regresi sederhana di atas, persamaan regresi berganda dapat digambarkan sebagai berikut:

Ln Harga Saham = 7,855 +

$0,002(\mathrm{DPR})+0,859(\ln \mathrm{EPS}) \quad-$

\section{Uji Hipotesis}

Adapun hasil pengolahan data dapat dilihat pada Tabel 2 sebagai berikut:

Tabel 2. Uji t

Coefficients $^{\mathrm{a}}$

\begin{tabular}{ccccccc}
\hline & & \multicolumn{2}{c}{ Unstandardized Coefficients } & $\begin{array}{c}\text { Standardized } \\
\text { Coefficients }\end{array}$ & t & Sig. \\
\cline { 2 - 5 } & & B & Std. Error & Beta & & \\
\hline 1 & (Constant) & 7.855 & 1.006 & & 7.807 & .000 \\
& DPR & .002 & .002 & .061 & .993 & .327 \\
& InEPS & .859 & .058 & .924 & 14.690 & .000 \\
& KURS & .000 & .000 & -.262 & -4.738 & .000 \\
\hline a. & Dependent Variable: InSAHAM & & & & \\
\hline
\end{tabular}

Tabel 2 menunjukkan nilai signifikansi t hitung variabel ln earning per share dan kurs dollar lebih kecil dari 5\%, berarti secara individual variabel ln earning per share dan kurs dollar berpengaruh signifikan terhadap variabel perubahan ln harga saham. Sedangkan nilai signifikan $\mathrm{t}$ hitung variabel dividend payout ratio lebih besar dari 5\%, berarti secara individual variabel dividend payout ratio tidak berpengaruh signifikan terhadap ln harga saham. Dengan demikian, sudah cukup bukti untuk menerima hipotesis kedua dan ketiga, namun tidak cukup bukti untuk menerima hipotesis yang pertama.

Adapun hasil pengolahan data dapat dilihat pada Tabel 3 sebagai berikut:

Tabel 3. Uji F

\begin{tabular}{|c|c|c|c|c|c|c|}
\hline \multicolumn{7}{|c|}{ ANOVA $^{\mathbf{b}}$} \\
\hline & Model & Sum of Squares & df & Mean Square & $\mathbf{F}$ & Sig. \\
\hline \multirow[t]{3}{*}{1} & Regression & 106.142 & 3 & 35.381 & 100.555 & $.000^{\mathrm{a}}$ \\
\hline & Residual & 13.370 & 38 & .352 & & \\
\hline & Total & 119.513 & 41 & & & \\
\hline
\end{tabular}

a. $\quad$ Predictors: (Constant), KURS, DPR, InEPS

b. Dependent Variabel: InSAHAM

Dengan melihat nilai signifikansi $\mathrm{F}_{\text {hitung, }}$ sebesar 0,000 berarti lebih kecil dari 5\%, maka variabel dividend payout ratio, earning per share, dan kurs secara bersama - sama berpengaruh signifikan terhadap variabel perubahan harga saham. 
Hasil penelitian menunjukkan bahwa secara simultan terdapat pengaruh antara dividend payout ratio (DPR), earning per share (EPS) dan kurs dollar terhadap perubahan harga saham perusahaan yang terdaftar di BEI periode pengamatan tahun 2016-2018 dengan jumlah sampel sebanyak 14 perusahaan. Total dari sampel yang diambil adalah sebesar 42 . Pengaruh tersebut ditunjukkan nilai signifikan F hitung $<5 \%$, ini berarti secara simultan ada pengaruh variabel bebas terhadap variabel terikat. Dengan jumlah F hitung $=100,555$ dengan signifikansi 0.000 . Sehingga terbukti secara simultan ada pengaruh antara variabel bebas dividend payout ratio (DPR), earning per share (EPS) dan kurs dollar terhadap variabel terikat harga saham.

Hasil penelitian di atas juga menunjukkan bahwa diterimanya hipotesis alternatif kedua dan hipotesis alternatif ketiga, sehingga secara parsial variabel earning per share dan kurs dollar berpengaruh signifikan terhadap harga saham. Pengaruh ini ditunjukkan pada tabel 2, yang menunjukkan nilai signifikan t hitung variabel earning per share dan kurs dollar lebih kecil dari 5\%, yaitu 0,000 dan 0,000. Penelitian ini membuktikan secara parsial ada pengaruh antara variabel bebas earning per share (EPS) dan kurs dollar terhadap variabel terikat harga saham. Dengan demikian hasil penelitian ini sejalan dengan hasil penelitian yang dilakukan oleh Rahmawati (2002) yang melaporkan bahwa EPS berpengaruh signifikan terhadap harga saham dan hasil penelitian dari Sitinjak dan Kurniasari (2003) dan Ocktavia (2007) yang menyatakan bahwa Kurs sebagai salah satu indikator yang mempengaruhi aktivitas di pasar saham. Namun hasil penelitian tidak cukup bukti untuk menerima hipotesis kedua, sehingga secara parsial variabel dividend payout ratio tidak berpengaruh signifikan terhadap harga saham. Pada tabel diatas menunjukkan bahwa nilai signifikan t hitung variabel dividend payout ratio lebih besar dari $5 \%$, yaitu 0,327. Sehingga secara parsial variabel bebas dividend payout ratio tidak berpengaruh signifikan terhadap variabel terikat harga saham. Hasil penelitian ini juga sejalan dengan hasil penelitian yang dilakukan oleh Nurmala (2006) yang menunjukkan bahwa kebijakan dividen tidak mempunyai pengaruh terhadap harga saham pada perusahaan otomotif yang telah go publik di Bursa Efek Jakarta (BEJ).

\section{SIMPULAN DAN SARAN}

\section{Simpulan}

a. Berdasarkan hasil analisis data menunjukkan bahwa hipotesis alternatif pertama ditolak. Ini berarti variabel bebas dividend payout ratio tidak berpengaruh positif signifikan terhadap harga saham perusahaan manufaktur yang terdaftar di BEI pada tahun 2016 sampai pada tahun 2018. Hal ini sesuai dengan hasil penelitian dari Nurmala (2006), hasil penelitiannya menunjukkan bahwa kebijakan dividen tidak mempunyai pengaruh terhadap harga saham.

b. Berdasarkan hasil analisis data menunjukkan bahwa hipotesis alternatif kedua dapat diterima. Ini berarti variabel bebas earning per share berpengaruh positif signifikan terhadap perubahan harga saham perusahaan manufaktur yang terdaftar di BEI pada tahun 2016 sampai 2018. Hal ini sesuai dengan hasil penelitian Rahmawati (2002) yang memberikan kesimpulan bahwa EPS berpengaruh signifikan terhadap harga saham.

c. Berdasarkan hasil analisis data menunjukkan bahwa hipotesis alternatif ketiga dapat diterima. Ini berarti variabel bebas kurs dollar berpengaruh negatif signifikan terhadap perubahan harga saham perusahaan manufaktur yang terdaftar di BEI pada tahun 2016 sampai 2018. Hal ini sesuai dengan hasil penelitian dari Ocktavia (2007).

d. Secara bersama-sama, variabel bebas dividend payout ratio, earning per share dan kurs dollar berpengaruh signifikan terhadap perubahan harga saham perusahaan manufaktur yang terdaftar di BEI pada tahun 2016 sampai tahun 2018. Hal ini ditunjukkan dari nilai signifikansi $\mathrm{F}$ hitung sebesar 0,000 yang lebih kecil dari 5\%.

\section{Keterbatasan Penelitian}

a. Populasi dalam penelitian ini hanya terbatas pada satu jenis perusahaan yaitu perusahaan manufaktur. Hal ini mengakibatkan penelitian ini tidak bisa digeneralisasi untuk semua jenis perusahaan.

b. Terjadi fenomena tidak normalnya variabel dividend payout ratio, berarti 
terjadi penyimpangan asumsi klasik terhadap model regresi.

\section{Saran}

a. Bagi peneliti selanjutnya, tidak membatasi pada satu jenis perusahaan saja, hal ini bertujuan agar dapat digeneralisasi untuk jenis perusahaan yang lain.

b. Menambah periode dan melonggarkan kriteria pengambilan sampel supaya jumlah perusahaan yang diobservasi bertambah, dengan demikian memperbesar data yang dianalisis.

\section{REFERENSI}

Abdul Halim. 2003. Analisis Investasi. Jakarta: Salemba Empat.

Amanda, Astrid. 2013. Pengaruh Debt to Equity Ratio (DER), Return on Equity (ROE), Earning Per Share (EPS), dan Price Earning Ratio (PER) terhadap Harga Saham (Studi pada Perusahaan Food and Beverages yang terdaftar di Bursa Efek Indonesia tahun 20082011). Jurnal Administrasi Bisnis. Universitas Brawijaya. Vol 4, No 2, p.245-256.

Ananto Sarono Wicaksono. 2007. Analisis Pengaruh Rasio Keuangan terhadap Harga Saham Perusahaan yang Terdaftar di Bursa Efek Jakarta. Skripsi S1 Ekonomi UNNES, Semarang.

Ana Ocktavia. 2007. Analisis Pengaruh Nilai Tukar Rupiah/US\$ dan Tingkat Suku Bunga SBI terhadap Indeks Harga Saham Gabungan di Bursa Efek Jakarta. Skripsi S1 Ekonomi Universitas Negeri Semarang, Semarang.

Bambang Pranowo. 2009. Pengaruh Beberapa Kinerja Keuangan terhadap Harga Saham Perusahaan. Jurnal Ekonomi Bisnis, 14 (3).

Bambang Riyanto. 1998. Dasar-dasar Pembelanjaan Negara. Edisi Keempat. Yogyakarta: Penerbit BPFE.
Elyzabeth Lucky Maretha Sitinjak dan Widuri Kurniasari. (2003). Indikator-Indikator Pasar Saham dan Pasar Uang yang Saling Berkaitan Ditinjau dari Pasar Saham sedang Bullish dan Bearish. Jurnal Riset Ekonomi dan Manajemen, 3(3).

Esti Puji Astuti. 2005. Pengaruh Earning Per Share (EPS), Price Earning Ratio (PER), dan Debt to Equity Ratio (DER) terhadap Return Saham pada Perusahaan Properti yang Terdaftar di Bursa Efek Jakarta. Skripsi S1 Ekonomi UNNES. Semarang.

E. Rahmawati. 2002. Analisis Earning Per Share, ROE, dan Debt to Equity Ratio Terhadap Harga Saham Studi Manufaktur di BEJ. Skripsi S1 UMY, Yogyakarta.

Fahmi, Irham. 2012. Manajemen Investasi. Teori dan soal jawab. Jakarta: Salemba Empat

Gunawan Sumodiningrat. 2007. Ekonometrika Pengantar. Edisi 2. Yogyakarta: BPFE.

Hamdy Hadi, 2013, Manajemen Keuangan Internasional. Edisi Ketiga. Jakarta: Mitra Wacana Media.

Hanafi, M. M. dan Halim, A. 2009. Analisis Laporan Keuangan. Edisi Keempat. Yogyakarta: YKPN.

Henry Simamora. 2000. Akuntansi Basis Pengambilan Keputusan Bisnis Jilid II. Jakarta: Salemba Empat.

I Dewa Made Arya Sanjaya. 2017. Pengaruh Return on Equity, Debt to Equity Ratio, Price Earning Ratio, dan Earning Per Share terhadap Harga Saham (Studi pada Perusahaan Manufaktur sektor Otomotif \& Komponen yang terdaftar di Bursa Efek Indonesia). Jurnal Ilmiah Mahasiswa FEB (JIMFEB). Universitas Brawijaya. Vol 6, No 1.

Imam Ghozali. 2001. Aplikasi Analisis Multivariet dengan Program SPSS. Universitas Diponegoro: Semarang. 
Imam Ghozali. 2002. Aplikasi Analisis Multivariate dengan Program SPSS. Edisi 2. Universitas Diponegoro: Semarang.

Itjang D. Gunawan. 2003. Transaksi Derivatif, Hedging, dan Pasar Modal. Jakarta: Grasindo.

James C. Van Horne dan John M. Wachowicz. 1997. Prinsip-prinsip Manajemen Keuangan. Jakarta: Salemba Empat.

Jeff Madura. 1993. Financial Management. Florida University Express.

Jogiyanto. 2000. Teori portofolio dan analisis investasi. Edisi 2. Yogyakarta: BPFE.

Kasmir. 2008. Bank dan Lembaga Keuangan Lainnya. Edisi Revisi 2008. Jakarta: PT. Rajagrafindo Persada.

Linzzy Pratami Putri, (2015). Pengaruh Profitabilitas terhadap Harga Saham pada Perusahaan Pertambangan Batubara di Indonesia. Jurnal Ilmiah Manajemen dan Bisnis, 16(2), 49-59

Madichah. 2005. Pengaruh Earning Per Share (EPS), Dividend Per Share (DPS), dan Financial Leverage (FL) terhadap Harga Saham Perusahaan Manufaktur di Bursa Efek Jakarta. Skripsi S1 Ekonomi UNNES, Semarang.

Martono dan Harjito, A. 2002. Manajemen Keuangan, Edisi Pertama, Cetakan Kedua, Yogyakarta: Ekonista

Mohamad Abdul Azis. 2005. Pengaruh Earning Per Share (EPS) dan Pertumbuhan Penjualan terhadap Perubahan Harga Saham pada Perusahaan Makanan dan Minuman yang Terdaftar di Bursa Efek Jakarta. Skripsi S1 Ekonomi UNNES, Semarang.

Mohamad Samsul. 2006. Pasar Modal dan Manajemen Portofolio. Jakarta: Erlangga.
Mudrajad Kuncoro. 1996. Manajemen Keuangan Internasional. Yogyakarta: BPFE.

Nurmala. 2006. Pengaruh Dividen terhadap Harga Saham Perusahaan-Perusahaan Otomotif di bursa Efek Jakarta. Jurnal Mandiri, 9 (1).

R. Damayanti. 2001. Analisis Dividen Payout Ratio, "Earning per share, dan Return of Invesment dalam mempengaruhi harga saham industri semen di BEJ. Skripsi S1 UMY. Yogyakarta.

Suad Husnan. 1994. Dasar-dasar Teori Portofolio dan Analisis Sekuritas. UPP AMP YKPN, Yogyakarta.

Suad Husnan. 1998. Manajemen KeuanganTeori dan Penerapan (keputusan jangka panjang). Edisi 4. Yogyakarta: BPFE.

Tandelilin Eduardus. 2001. Analisis Investasi dan Manajemen Portofolio. Edisi 1. BPFE: Yogyakarta

Thian. 2001. Panduan Investasi Saham. Jakarta: Ghalia Indonesia.

Tomi Sanjaya. (2015). Pengaruh Return on Equity (ROE), Debt to Equity Ratio (DER), Earning Per Share terhadap Harga Saham (Studi pada perusahaan Food and Beverages yang terdaftar di Bursa Efek Indonesia Periode 20112013). Jurnal Administrasi Bisnis. Universitas Brawijaya, 23(1).

Yarnest. 2004. Panduan Aplikasi Statistik dengan Menggunakan SPSS Versi 11.00. Malang: Dioma.

Yogo Purnomo. Keterkaitan Kinerja Keuangan dengan Harga Saham (Studi Kasus 5 Rasio Keuangan 30 Emiten di BEJ Pengamatan 1992-1996). Usahawan No. 12 Tahun 1998.

Yunika Kurnia Sari. 2009. Pengaruh Dividend Payout Ratio (DPR), Earning Per Share (EPS), terhadap Harga Saham Perusahaan Manufaktur yang terdaftar 
di Bursa Efek Jakarta. Skripsi S1

Ekonomi UMS, Surakarta. 
JRAK, Volume 17, No.1 Februari 2021 